This is an electronic version of an article published in Diplomacy and Statecraft, 16: 699-722, 2005. Diplomacy and Statecraft is available online at:

\title{
Lord Home and Anglo-American Relations, 1961-1963
}

\begin{abstract}
ANDREW HOLT
This article focuses on the role of Lord Home, the British Foreign Secretary, in the conduct of AngloAmerican relations between 1961 and 1963. It studies three controversial policy areas: the newly independent states of Laos and the Congo, along with the debate over the decolonisation of British Guiana; the key Cold War issues of Berlin and Cuba; and a variety of nuclear weapons-related matters. It is argued that Home, in constantly striving to maintain the alliance, was more pro-American than Macmillan. He exercised an important restraining and calming influence on the Prime Minister, preventing him from pursuing potentially damaging initiatives. However, the relationship between the two men was strong. Home's diplomacy usually complimented Macmillan's interventions and they often worked together.
\end{abstract}

\section{I}

On the morning of 25 July 1960, Britain awoke to a media frenzy. The Daily Mail derided Conservative Prime Minister Harold Macmillan for 'making a fool of himself'. ${ }^{1}$ The Daily Mirror went further, decrying 'the ludicrous selection' that 'will reduce the British Foreign Office to a laughing stock in the capitals of the world'. ${ }^{2}$ It was the appointment of the Earl of Home as Foreign Secretary that raised the press's ire. Home was a lesser known minister, and his status as a peer prompted Labour Party leader Hugh Gaitskell to call the appointment 'constitutionally objectionable'. ${ }^{3}$ Eventually the storm subsided, leaving Home to occupy the Foreign Office at a crucial time. The Macmillan years have been described as some of closest and most successful in Anglo-American relations, ${ }^{4}$ yet opinions on Home's term are mixed. The left-wing Labour MP Emrys Hughes wrote that had Macmillan sacked Home in 1962 , 'it would have been understandable'. ${ }^{5}$ Other contemporaries were more positive. The Press soon changed their tune: 'How wrong we were about Home', conceded the Daily Mail. ${ }^{6}$ From the Foreign Office, Joseph Godber, Minister of State, felt that Home 'never made a position worse and he often made it better' ${ }^{7}$ and the FO generally was impressed by its new head. ${ }^{8}$ Macmillan too was satisfied with his 
decision, ${ }^{9}$ which the historian John Ramsden contends 'did turn out rather well'. ${ }^{10}$ Home's succession to the premiership in October 1963 strengthens this case.

Home's relationship with his Prime Minister has received little attention, although there is general agreement that he was 'a perfect foil for Macmillan's showmanship'. ${ }^{11}$ His integrity, shrewdness, judgement and willingness to say unpopular things compensated for Macmillan's impetuousness. D. R. Thorpe highlights Home's role as a source of advice and reassurance to the Prime Minister, especially after Macmillan replaced a large chunk of his Cabinet in July $1962 .{ }^{12}$ There is less consensus on who controlled foreign policy. One group of authors attributes primacy to the Prime Minister. According to his biographer, Macmillan was 'his own Foreign Secretary (certainly on all the major issues) ${ }^{13}$ and John P. S. Gearson agrees that Macmillan's 'position was unchallenged in the field of foreign affairs'. ${ }^{14}$ Home's Foreign Office colleagues support this. To them, Home was not inclined to seek the limelight and was happy to concentrate on other areas. ${ }^{15}$ In contrast, another school holds that Macmillan believed in delegation and non-interference. ${ }^{16}$ As John Dickie put it 'The Prime Minister was never a meddler in the running of the Foreign Office during Lord Home's term of office'. ${ }^{17}$ Lord Kilmuir concurred, asserting that with Home's appointment, 'The Foreign Office, which had virtually been under the personal direction of the Prime Minister since 1955, once again began to function as it should do'. 18

It is difficult to disentangle Home's role from Macmillan's other than through a close examination of archival sources. Using such an approach, this article sheds light on this important area by addressing two key questions. First, it analyses Home's role in Anglo-American relations, both in conversing with US representatives and shaping policy. Secondly, it examines his association with Macmillan. The three broad areas in which the 'special relationship' was most tested are analysed, covering a range of 'high' and 'low' issues. The first differences appeared in attitudes to civil wars in newly independent states, most notably Laos and the formerly Belgian Congo. The US also opposed plans to grant British Guiana independence. Moreover, divergences were present over the Cold War 'hot-spots' of Berlin and Cuba. Finally, disagreements over nuclear weapons will be considered. Relations became strained over nuclear co-operation with third parties, the US cancellation of the Skybolt missile and plans for a Multilateral Nuclear Force (MLF). Contrastingly, the signing of the limited Test-Ban Treaty represented a triumph of Anglo-American co- 
operation. The analysis proceeds in the context of previous relationships between Prime Ministers and Foreign Secretaries.

There has often been tension between forceful Prime Ministers and their Foreign Secretaries. Lord Curzon under David Lloyd George (1918-1922), Arthur Henderson under Ramsay MacDonald (1929-1931), and Anthony Eden under Winston Churchill (1951-1955) are prime example. Furthermore, Selwyn Lloyd under Eden (1955-1957) and Macmillan (1957-1960) found himself permanently overshadowed by prime ministerial intervention in foreign policy matters. Three key themes emerge from this literature: personality clashes, prime ministerial interference in foreign policy and a sometimes uneasy division of responsibilities. Personal friction is most apparent in the first two of the above cases. Curzon 'brought out the spiteful side of Lloyd George's nature ${ }^{19}$ and the Prime Minister often attacked and denigrated him in Cabinet. There was also unpleasantness between MacDonald and Henderson. MacDonald 'sniped at the Foreign Secretary's lack of competence, hamstrung his initiatives, and maligned him in the presence of politicians and trade union leaders'. ${ }^{20}$

Prime ministerial interference in foreign affairs often exacerbated these personality clashes. MacDonald set a trend days after coming to power when, as the FO was attempting to improve Anglo-French relations, he authorised a Sunday Times article criticising France for her treatment of minorities. ${ }^{21}$ Eventually Henderson snapped. As the issue of a loan from France to Germany was considered in 1931, he 'began to pursue a personal foreign policy with a reckless disregard of the Prime Minister's views'.22 Lloyd George also tried to circumvent the Foreign Office. He had his own advisers on foreign policy, the Secretariat (or 'Garden Suburb'), which Curzon resented. In 1922, Lloyd George used Lord Derby to arrange a meeting with French Premiere Raymond Poincaré. An outraged Curzon learned of this via the French press. The Prime Minister would even actively undermine Curzon's policies, like his efforts to secure peace between Greece and Turkey in March 1921. Churchill's interference in foreign policy began during World War II and continued in peace-time, often on trivial matters. As Prime Minister during the Suez crisis, Eden went further. According to Rab Butler, he was 'much nearer to being a dictator than Churchill at the height of the war'. ${ }^{23}$ Macmillan was similarly dominant. As Selwyn Lloyd commented, he 'modelled himself upon an American President, with subordinates, not colleagues'. ${ }^{24}$ 
Such attitudes sometimes resulted in a division of responsibilities. This was most marked in the second Labour Government, where MacDonald took charge of Anglo-American relations, and became less critical of Henderson in return. The division took a different form under Lloyd George, who in relation to Germany, for example, took control of many key decisions and negotiations, but left Curzon to develop the detail. Curzon actually had no wish to intervene in the Adriatic controversy or relations with France. The same was true of the European aspect of Russian policy as Curzon preferred the Asian dimension, on which he was very knowledgeable. Nicolson therefore argues that Lloyd George's conduct 'was not unwarrantable. Curzon was not unwilling'. ${ }^{25}$ There was no explicit division of role between Churchill and Eden, though the ageing Prime Minister became pre-occupied with decreasing Cold War tension. For example, the idea of meeting the Soviets engrossed Churchill in July 1954, leading him to propose a meeting with Molotov in spite of Eden's advice and resulting in resignation threats aplenty in the Foreign Office. In contrast, the relationship between Home and Macmillan was generally smoother, in spite of the Prime Minister's undoubted interference in foreign affairs.

Three recently, or soon to be, independent states caused tension in AngloAmerican relations. In Laos, both Home and Macmillan used their influence to help steer the US away from large-scale armed involvement, though the evidence shows that the Prime Minister's role was greater. Home nevertheless played a part with his diplomacy both in Washington and Geneva. His attitude to two key issues, funding military operations and military intervention, demonstrates his prioritisation of relations with the US. Nigel Ashton correctly states that, 'for the most part during the Kennedy Presidency the question of decolonisation did not figure highly on the list of Anglo-American problems'. ${ }^{26}$ There were two exceptions to this. The first was the Belgian Congo, on which Home dominated policy. His beliefs were the main determinant of the British approach and concern for British interests and especially Rhodesia influenced these. The Foreign Secretary uncharacteristically and vehemently opposed the US on the Congo. He was hostile to the cost of the operations, the role of the United Nations, the implementation of sanctions and the use of force. He also opposed the US on British Guiana, arguing against the resumption of direct rule, but his role diminished as Macmillan became more involved. 
The Laotian war broke out in 1959 and peaked as the Kennedy Administration took office. It became 'a running sore between the Americans and British'. ${ }^{27}$ A senior Cabinet colleague praised Home's 'masterly triumph', by which 'he gradually wooed the American Government away from a major military intervention in Laos'. ${ }^{28}$ However, whilst the archives show that British ministers helped steer the US away from a major operation, the role of Macmillan was greater. Both Ormsby-Gore and the historian Nigel Ashton highlight the importance of the Prime Minister's advice in reinforcing Kennedy's existing doubts. ${ }^{29}$ Although the President never actually said he agreed with Macmillan, he scaled down US contingency planning after the Prime Minister expressed his concerns at Key West.

The Foreign Secretary contributed via diplomacy. US policy-makers were very reluctant to attend the second Geneva conference on Laos. Home, the joint chairman, had some doubts too, but urged the Americans not to denigrate the idea, especially once the Soviets showed a willingness to respect it. At the outset of the conference Britain favoured a neutral Laos, but US decision-makers were unenthusiastic. Home played an important part in overcoming this, performing 'what many observers regarded as a diplomatic tour de force in persuading the various pressure groups to drop their blocking tactics' so that the real problems could be tackled. $^{30}$ The Conference reached agreement on a neutral Laos 14 months later, though after a few days Home had left negotiations in the hands of Malcolm MacDonald.

Back at home, the Foreign Secretary argued that the US expected a greater British financial contribution to the operations in Laos. Macmillan opposed giving money and a senior Treasury official considered Home's proposals to be 'far more than I would regard as justified by the normal standards for a country such as Laos'. ${ }^{31}$ The Foreign Secretary, however, got his way. His attitude to military intervention illustrated once more his pro-US views. In March 1961, he felt that 'if America after weighting everything decides to go in, I fear we must support them but the prospect is horrible'. The Prime Minister initially agreed, but soon began to have doubts. By July, he was even questioning whether 'we ought now to review our whole position regarding SEATO', but Home's position did not change. ${ }^{32}$ He was also keener to set the terms of reference for military planning. ${ }^{33}$

Chaos broke out in the former Belgian part the Congo (now called Zaïre) soon after it declared independence in June 1960. It was over two years before the wealthy 
break-away province of Katanga (now Shaba), led by Moise Tshombe, was subdued. Macmillan boasted that 'Kennedy and I, we drove the Russians out', ${ }^{34}$ but the Prime Minister only began paying close attention to the Congo in 1962 as the breach with the US widened. Even when the issue came up at Nassau in December, 'The Prime Minister called on Lord Home to speak'. ${ }^{35}$ Home's control of British policy 'was a reality; it extended to details; and it was very distinctive'. ${ }^{36}$ Macmillan intervened rarely, and these demonstrated his agreement with his Foreign Secretary. On sanctions for example, the Prime Minister was 'in full agreement with [Home's] assessment'. Similarly, he complained to President Kennedy in September 1961 about the growing UN interference in the Congo and later told him that he could 'not see how we in the United Kingdom could support a further United Nations operation in present circumstances' ${ }^{37}$

Home's beliefs and personality had a major influence on British policy. Racial considerations affected his concerns. He argued that force would be needed to back an imposed settlement because Tshombe "would rather go back to eating nuts than capitulate'. ${ }^{38}$ More importantly Home 'was less flexible and more consciously principled a person than his Prime Minister'. ${ }^{39}$ He seemed to place his values above harmonious relations with the US in this instance. Unrepentant about opposing the will of the Security Council, he stated that 'We cannot change our views' on the American plan to increase economic pressure. Similarly, when asked in September 1962 if he could not agree to be silent on sanctions, he replied that 'he could not since he had already opposed, and could not go back on what Britain had said'. Even as late as December, he still urged that 'we ... get the UN out within the next few months' and threatened that if a resolution authorising the use of force appeared, 'we should almost certainly have to veto it'. ${ }^{40}$

British interests in the region ensured that Home and the Foreign Office could not stand aside. The British-owned Tanganyika Concessions controlled 14.5 per cent of the leading mining company, Union Minière. However, the Rhodesias were the key to the Foreign Secretary's position. The Katangan mines ran contiguously with Northern Rhodesia's and Home feared the trouble spreading. ${ }^{41}$ Sir Roy Welensky, Prime Minister of the Federation of Rhodesia and Nyasaland, described Tshombe as potentially 'a very good friend to the West'. '[W]e will not stand idly by and watch Mr. Tshombe destroyed', Welensky threatened, stoking Home's fears that of a deal between the two. ${ }^{42} \mathrm{UN}$ action also had implications for South Rhodesia. The Foreign 
Secretary 'Stressed that if sanctions applied, next step would be for UN to vote sanctions against UK re Southern Rhodesia'. ${ }^{43}$ The use of force raised even greater concerns. $^{44}$

Anglo-American differences first surfaced in the summer of 1961. In December, The Times commented that 'It is becoming increasingly apparent that Anglo-American differences in the conduct of Congo policy are as serious as any since the Suez crisis'. ${ }^{45}$ The Foreign Secretary frankly encouraged Rusk to change policy. ${ }^{46}$ The first disagreement centred on the cost of operations in the Congo. Home considered withdrawing funds, but thought that the US would still contribute and worried that the USSR might step in. On a visit to Washington, he asked Kennedy 'how much longer the United States and the United Kingdom were going to keep on paying the bill without calling the tune a little more'. ${ }^{47}$ The Foreign Secretary became increasingly disillusioned with the United Nations. He viewed the UN as a peace keeping body and argued that it 'cannot take over the task of government in these huge and unruly countries where the primary task for years ahead will be to prevent civil war'. ${ }^{48}$ As Bundy astutely observed, Britain 'seemed to feel that the UN was a damned nuisance'. 49

The issue of economic sanctions was even more contentious. Home 'expressed flat opposition to sanctions', warning that they would have 'disastrous effects'. ${ }^{50}$ When the US persisted and pressured the UN to propose a boycott of Katangan copper, Britain refused to adhere, suspicious because much of the world's copper was in American hands. ${ }^{51}$ She continued to distance herself from tougher schemes and remained resolute at the Anglo-US-Belgian talks, much to the State Department's displeasure. The Foreign Secretary's main concern, however, was to prevent the use of force. He was reluctant to back a resolution on the Congo, fearing that the UN might use it to impose its will on Katanga, ${ }^{52}$ and he remained consistently opposed to military action. After the US backed intervention from September 1961, Britain would not help the operation, refusing over-flying rights to UN aircraft. The UN appeal for British bombs proved especially controversial. Home was 'not sure about this', ${ }^{53}$ but the Cabinet agreed to supply the bombs, albeit with conditions. (The request was ultimately withdrawn.) Rusk claimed to believe that the European powers should take the lead in Africa, ${ }^{54}$ but there is little evidence of this. Kennedy prioritised keeping the USSR out of Africa over British interests, and logistical contributions gave the US a 
stronger hand. Home thus chose in 1962 to stand aside to avoid causing gratuitous offence to the Americans. ${ }^{55}$ For Britain, 'the game was not worth the candle'. 56

Despite applying pressure on the Congo, the US Government was most concerned with British Guiana. After Cheddi Jagan's leftist People's Progressive Party narrowly won the August 1961 election, the Kennedy Administration feared that the colony would go the way of Cuba. Macmillan looked on the lighter side: 'it is ... rather fun making the Americans repeat over \& over again their passionate plea to us to stick to "colonialism" and "imperialism" at all costs'. ${ }^{57}$ The President, however, felt that most foreign policy problems 'paled in comparison with the prospect of the establishment of a Communist regime in Latin America'. ${ }^{58}$ Britain had 'no strategic interest in British Guiana and the sooner we can shed our obligations there the better', but as Rusk stressed, British interest was significant in the context of Anglo-American relations. ${ }^{59}$

Lord Home's role diminished as the crisis drew to a close. Macmillan became increasingly involved as the tension rose and Kennedy insisted that two sessions of the June 1963 Birch Grove meeting be devoted to the issue. Before this however, he requested that Rusk meet Home and the Colonial Secretary, Duncan Sandys. Sandys took the lead for the British side during this conversation and, with Kennedy, also dominated the discussion at Birch Grove. ${ }^{60} \mathrm{Up}$ until this point however, Home corresponded on the issue regularly with his opposite number and personally discussed it with him. He was not afraid to be blunt, leaving Kennedy wondering 'whether the Foreign Secretary's correspondence had been a bit "sharp" in tone'. ${ }^{61}$ Home pressed his view of Jagan, as 'a confused thinker' who 'has not, since 1957, proved as difficult to deal with as he was earlier' and steadfastly opposed excessive interference in British Guiana's affairs. His response to Rusk's February 1962 approach to do so was as 'cold as the arctic', questioning how an elected leader could be prevented from holding office in a democracy. A few months later he wrote that 'if we tried anything ... we should only make matters worse'. ${ }^{62}$

Home's motives for opposing this were mixed. He was mindful of the interests of the Guianan people. Resuming direct rule risked Cuba declining to buy rice from British Guiana. Having agreed to purchase 40,000 metric tons in 1963-64, such a move would put the industry 'in grave difficulty'. ${ }^{63}$ Three key themes in the Foreign Secretary thinking reappeared however. Firstly, he, like Macmillan, was worried about the financial cost of resuming direct rule. He emphasised the importance of 
American financial assistance if direct rule was resumed, thinking it impracticable and dangerous' without this. ${ }^{64}$ Concern for the UN was the second theme. Home said that the resumption of direct rule would 'destroy Britain's image as a decolonising power'. This, he feared, would cause problems in dealing with Southern Rhodesia, the

third factor. ${ }^{65} \mathrm{He}$ worried that direct rule would raise questions about why Britain did not do the same there.

Home's influence over British policy in these areas was significant. Macmillan was not especially interested in colonial affairs, and became personally involved only when relations with the US or USSR were at stake. For this reason, he took more of an interest in Laos and British Guiana than the Congo. On Laos, the Foreign Secretary was more conciliatory towards the US than the Prime Minister, winning extra funding for operations and taking a more positive attitude to contingency planning. Conversely, on the Congo, where his control was greatest, Home showed that he was not afraid to oppose the US, yet he did not want to go too far. When Macmillan did become involved, as over British Guiana, Home remained intimately involved in discussions, but his chief took greater decision-making power. The Foreign Secretary opposed the US for a number of reasons. He was keen to protect British economic interests, which also partly explains his attitude to Katanga and to sanctions. This contrasts with his readiness to make concessions over Cuba, which was less important to Britain as a market. Furthermore, Home was concerned throughout with the strain on British financial resources. He was eager to remove the expense of Guiana and found having to pay for the UN operation in the Congo infuriating. Rhodesia was most important to him however. Fear for Northern Rhodesia drove the Foreign Secretary's policy on the Congo and also influenced his opposition to resorting to direct rule in British Guiana.

\section{III}

Two issues threatened to bring the Superpowers to war in this period. On Berlin, Home stood firm against Soviet threats. However, like Macmillan, he favoured negotiations and eschewed economic sanctions and military contingency planning, causing disagreement with the Americans. The two men thus worked together to deflect criticism of Britain whilst minimising British commitments, though the Foreign Secretary was the keener of the two to appease the US. The allies also differed on Cuba. The Cabinet opposed trade sanctions, but Home favoured 
concessions to the Americans. This led to conflict with the Board of Trade over credit reporting, the Coordinating Committee for Multilateral Export Controls (COCOM) list (which restricted trade with Eastern bloc states) and the sale of Leyland buses to Cuba. When the Cuban missile crisis erupted in October 1962 the British role was limited but helpful. Home contributed personally by both steadying and restraining the Prime Minister.

The US, Britain, France and the Soviet Union jointly occupied Berlin. Soviet leader Nikita Khrushchev threatened to sign a peace treaty with the GDR, leaving access to West Berlin under East German control. Home supported the Americans and remained firm in the face of Russian threats. Working with Rusk, he repeatedly assured Gromyko of Western resolve. The Foreign Secretary's intervention could yield direct and beneficial results. After giving Gromyko 'unshirted hell' ${ }^{, 66}$ for the dropping of chaff in Western air corridors to interfere with radar, the Soviet action stopped within hours. Despite this public firmness however, Home and Macmillan both emphasised negotiation. The Foreign Secretary thought this necessary, 'if only in order to strengthen our hand with public opinion'. ${ }^{67}$ He thought the same was true of NATO. Furthermore, Home believed it possible to move the Soviets by argument. ${ }^{68}$ Thus, in April 1961 he pressed the Americans to negotiate and repeated this in June, though he did not suggest that negotiations should begin immediately. ${ }^{69}$ The Foreign Secretary own initiatives both failed however. Soviet opposition foiled his renewed efforts in October 1961 to establish a UN presence in Berlin, whilst West German Chancellor Konrad Adenauer successfully opposed his joint plan with Rusk to establish an international access authority.

Shlaim, Jones and Sainsbury argue that Home was more wary than Macmillan of making concessions to the USSR, ${ }^{70}$ but the evidence suggests otherwise. The Foreign Secretary told the US that the 'right of conquest' was 'wearing thinner year by year' and even considered accepting Soviet troops in West Berlin. By December 1961, he was arguing that the West might have to compromise on the recognition of East Germany and of the Oder-Neisse line, occupation rights, and links between West Berlin and West Germany ${ }^{71}$ - a comprehensive list. The Prime Minister urged the same. By then however, Home had become concerned that the Americans were 'almost too keen' on negotiations. He worried that this could weaken the effect of the US military build up and push France and West Germany together in opposition to 
talks, harming Britain's EEC application. He therefore tried to restrain Rusk before the Paris NATO meeting. ${ }^{72}$

This emphasis on negotiations came at the expense of other initiatives, causing conflict with the US. Although Home also opposed maritime counter measures, ${ }^{73}$ the main area of division was over military contingency planning. Britain was already struggling with her global commitments and he gave warning of his reluctance to remove forces from other areas, such as the Far East and Kuwait. Even if Britain did increase her forces, Soviet superiority still meant that Home 'had not seen any possibilities which made much sense'. ${ }^{74} \mathrm{He}$ and Macmillan also thought US probing provocative and feared accidental war. After the Wall was erected, the Foreign Secretary thus minimised protest for fear of increasing tension. ${ }^{75}$

Home and Macmillan worked together over Berlin. Their policy was to keep British involvement to a minimum without giving the Americans cause to complain. Macmillan heeded Home's June 1961 advice not to say anything that could be interpreted as a sign of weakness. Similarly, as the refugee flow from East to West Berlin increased and the US reviewed contingency planning, Britain decided to do nothing overt in case the US made them "the scape-goat for the adoption of a "weak" policy'. This time, the Foreign Secretary 'with great skill protected himself and our country from this accusation'. ${ }^{76}$ Nevertheless, he was generally more sensitive to the US than the Prime Minister. He wrote that, 'We we must not give [Kennedy] cause to think that our resolution and readiness to take risks, if they are sensible ones, is any less than those of our major allies' and was prepared to consider 'making open preparations for full-scale war on a NATO basis'. He even favoured the reintroduction of 'Limited conscription'. ${ }^{77}$ Moreover, Home moderated his chief. He dissuaded Macmillan from approaching Kennedy directly to request the removal of the irascible US General, Lucius Clay. During the Berlin Wall crisis, Home remained calm, speaking to Macmillan every evening and successfully pressuring him to climb down after the Prime Minister attacked the press. ${ }^{78}$

Whilst the US disapproved of British policy on Berlin, many Americans viewed her position on Cuba as 'a gross act of betrayal'. ${ }^{79}$ This manifested itself most clearly in Britain's refusal to join trade sanctions. Overseas trade accounted for 40 per cent of British GNP, whilst the American figure was just six per cent. Home pressed his position onto the US, telling Rusk, with reference to Nasser and Mossadeq, that sanctions did not work. ${ }^{80}$ He gave Kennedy the same message three months later. In 
NATO, Britain persuaded the Political Committee to oppose both common economic measures that could become public, and the inclusion of Cuba in the COCOM list.

Whilst 'Macmillan perused a robustly independent approach to trade with Cuba in the face of increasing US pressure', Home sought to make concessions. Like over Berlin, he warned that 'we do not wish to seem less sympathetic to them than other NATO countries'. ${ }^{81}$ However, the President of the Board of Trade, Fred Erroll, opposed even the monitoring of exports to see if they contained any strategic material, fearing that this would leave Britain vulnerable to renewed calls for Cuba to be added to the COCOM list. Macmillan thought Erroll 'right in his argument' and Home grew increasingly concerned. Although he too opposed the extension of the COCOM list, the Foreign Secretary worried that the opposition to credit reporting could 'lead to a major row'. Yet Erroll remained resolute. Only when Home obtained Macmillan's support was he able to return to the Cabinet and secure approval for the FO position. ${ }^{82}$ Economic disagreements over Cuba did not end there. The issue of the expansion of the COCOM list reared its head again in 1963. The Foreign Office worried that the British refusal to comply would jeopardize $£ 2$ million of military aid, but Erroll again proved difficult. He feared setting a precedent 'which would be contrary to our whole policy of liberal trading'. On this occasion however, pressure from Home and the FO paid off and Erroll agreed to deny licences to export COCOM goods to Cuba. ${ }^{83}$ The Foreign Secretary was less successful over the sale of Leyland buses to Cuba. The Export Credits Guarantee Department was originally 'inclined to advise against cover being granted in this case', but Erroll minuted Reginald Maudling, the Chancellor of the Exchequer, to argue to the contrary and Maudling duly backed the deal. Despite Foreign Office protests, the Cabinet endorsed this decision. ${ }^{84}$ The Foreign Secretary later changed his view anyway. When Leyland won a further contract in January 1964 Home, by then Prime Minister, warned an irate President Johnson that to curtail trade would cause a surge of Anti-Americanism in the House of Commons. ${ }^{85}$ He was keen to protect British interests and ensure that the US should not dictate policy to her. ${ }^{86}$

On 14 October 1962, a major Cold War crisis erupted with the discovery of Soviet missiles in Cuba. H. G. Nicholas claims that Britain was 'not merely consulted ... but intimately involved' in managing crisis ${ }^{87}$ However, historians and participants alike generally agree that British influence was limited. Home himself wrote that 'Neither Britain nor France was consulted, but we were informed as events unfolded'. ${ }^{88}$ Nevertheless, Britain still played a useful role. She was primarily 
concerned to prevent the conflict spreading into Berlin and helped ensure that US forces in Europe were exempt from the potentially provocative Defence Condition (DEFCON) 3 alert status. At the UN, Britain supported the US and did not mention the blockade's dubious legality. Most of all, Britain led European and Commonwealth backing for the US. Macmillan helped persuade Canadian Prime Minister Diefenbaker to lend his support, whilst Britain's 'complete calm helped to keep the Europeans calm'. ${ }^{89}$

If Macmillan helped pacify other countries, then Home had a steadying influence on Macmillan, who had a nervous and vulnerable side. The two worked closely together from the outset, jointly considering the reply to Kennedy's speech announcing discovery of missiles. Home was present for all of Macmillan's hotline discussions with Kennedy, and the Prime Minister would often ask Home his views as Kennedy spoke. This continued after the crisis was over, with Macmillan at one point telling Kennedy, 'I will talk to Alec Home, who is here' ${ }^{90}$ Helping to maintain British passivity was the Foreign Secretary's most valuable act. He again restrained the Prime Minister, who 'retained a hankering to take the initiative on a summit meeting.' Furthermore, Home told both the Polish Ambassador and the Soviet Chargé d'Affaires that Britain had no intention of mediating. David Bruce believed this to 'have been most helpful to us', whilst Frank Roberts though it 'no doubt played a part in bringing Khrushchev to halt his Cuba blackmail'. ${ }^{92}$

These two crises reveal some interesting features both of Home's conduct of foreign policy and his relationship with Macmillan. The Foreign Secretary was committed to negotiations over Berlin, but perceived the different nature of the Cuban missile crisis and rebuffed Soviet attempts to secure British intervention. On both issues, he was the most pro-American member of the Cabinet. He was prepared to consider reintroducing conscription, whilst his desire to appease American sensibilities over Cuban trade caused some fierce Cabinet battles. Home triumphed over Erroll through force of argument on the COCOM list, but could emerge victorious in Cabinet on reporting only with Macmillan's support. During the Cuban crisis, Home, realising that British mediation would weaken the American position, supported and restrained Macmillan. The Prime Minister also took more of an interest in Berlin than in less high profile foreign policy issues like the Congo and the documents show more detailed co-operation between the two over the issue. Home often took the lead when both men attended meetings with US policy makers, ${ }^{93}$ but 
the two generally worked in tandem in opposing military planning whilst endeavouring to avoid appearing weak in American eyes.

\section{IV}

With Cold War tensions at their height, nuclear weapons were the subject of many Anglo-American debates. The first group of these related to co-operation between Britain and third parties. The US opposed Britain sharing her knowledge with France, causing a split between Home and Macmillan that was mirrored over whether Britain should deal with Israel. Direct Anglo-American co-operation was also at stake, with the US cancellation of the Skybolt missile provoking a major diplomatic crisis. Home and Macmillan both believed in the value of the independent deterrent, but faced opposition from the State Department's Europeanists. The matter was settled by Macmillan and Kennedy at the Nassau Conference, with the Foreign Secretary playing a minor but valuable supporting role. He was more involved in opposing the US plan for a multilateral nuclear force. At times he seemed lukewarm to the idea and he defended it to the Russians, but he steadfastly opposed it in discussions with US policy-makers. The Prime Minister also took the lead over disarmament, the third area, occasionally bypassing Home. The Test-Ban Treaty was a great achievement for which Macmillan deserves most credit on the British side. Home's contribution was significant however, as he laid the foundations for the agreement in conversations with Rusk and restrained the Prime Minister at critical moments, especially over summitry.

Macmillan hoped to use the prospect of nuclear co-operation to get France to accept British membership of the EEC, but Home was 'uneasy about such a policy'. Macmillan therefore tried to hide his intentions. He told Home that 'All this must wait, in my view, at least for some months', but continued to explore the possibility of an Anglo-French agreement outside the FO. The Minister of Defence, Harold Watkinson, hinted to his French opposite number at possible co-operation on a nuclear submarine and although Home was part of the delegation at Rambouillet, he was excluded from private meetings and misled about nuclear co-operation. ${ }^{94}$

The French approach to the British firm Foster Wheeler to supply a heat exchanger and other parts for a nuclear submarine revealed the differences between the Prime Minister and Foreign Secretary. Macmillan and Peter Thorneycroft, who replaced Watkinson in July 1962, were happy to agree to the request without 
considering the US. A Foreign Office memorandum conceded the ambiguity of the legal position, but an alarmed Home insisted that the US be consulted. The American opposition to the transaction outraged the majority of the Cabinet, but the Foreign Office accepted the decision, noting 'that the deciding factor must be ... the risks of wider damage to Anglo-American cooperation'. ${ }^{95}$ The US then agreed to supply France with a complete Nautilus nuclear powered submarine. Macmillan fumed, but Home again prioritised preventing a row with the Americans. ${ }^{96}$ The pattern repeated itself when US pressure on Foster Wheeler's parent company resulted in the rejection of a further French proposal. ${ }^{97}$

A similar situation occurred when Israel approached Britain to supply her with Hawk missiles after the US refused to do so. The Foreign Secretary counselled against the sale. His main concern was the US, 'since our own anti-aircraft missiles involve American information and we should need their permission to sell the weapons to Israel' ${ }^{98}$ No deal was done, but the Americans then changed their minds without fulfilling their promise to consult Britain. Macmillan was more furious than ever, warning Kennedy, without objection from Home, that 'It certainly makes it necessary to reconsider our whole position on this and allied matters'. ${ }^{99}$ The response of Lord Hood, Minister at the Embassy in Washington, suggests that the Foreign Secretary's reputation as a restraint was well known. Hood noted that Kennedy was yet to read Macmillan's message, and asked Home to prompt the Prime Minister to send a second more conciliatory one. ${ }^{100}$ Macmillan obliged.

Further tension arose when, in November 1962, the US finally cancelled the air-launched Skybolt missile, promised to Britain in 1960 to act as her independent nuclear deterrent. Of course, 'Britain had become so reliant on the Americans that the concept of an "independent nuclear deterrent" was nonsense', ${ }^{101}$ but the idea had become a symbol of British greatness to many Conservative backbenchers. Home and Macmillan both believed in an independent deterrent. ${ }^{102}$ The Americans, however, wanted Britain to focus on conventional capabilities, especially in light of events in Berlin, ${ }^{103}$ and feared that the British deterrent encouraged France to pursue her own nuclear programme. The Europeanists in the State Department, along with McNamara and Acheson, thus welcomed Skybolt's cancellation as a means of excluding Britain from the nuclear club.

The Europeanists did not win out. Britain secured the submarine-launched Polaris missile at the Nassau Conference, where dialogue between Kennedy and 
Macmillan predominated. ${ }^{104}$ US Ambassador David Bruce observed that the Prime Minister 'dominates his delegation'. ${ }^{105}$ The Foreign Secretary's role was limited to aiding Macmillan, who reported that 'Alec Home and Peter Thorneycroft are giving me splendid support in their different ways'. ${ }^{106}$ Their sheer presence strengthened Macmillan's hand by allowing him to present ideas as a joint approach. As usual, Home was more conciliatory towards the Americans. When Thorneycroft wanted to leave Nassau early, the Foreign Secretary sided with Ormsby-Gore against him. Home also contributed by telling Kennedy that a deal 'would have absolutely no effect on the French' and could strengthen support for the Multilateral Force (MLF). ${ }^{107}$

The MLF plan envisaged placing nuclear weapons under joint control. Its advantages were political, combining the British and French nuclear programmes and curtailing German nuclear aspirations by involving her in nuclear policy. However, 'From a military standpoint, M.L.F. was a complete nonsense'. ${ }^{108}$ Macmillan warned Kennedy in June 1963 that Britain opposed the idea. He also thought associating Germany with nuclear weapons would do great damage to détente. Furthermore, whilst Britain would surrender her entire nuclear arsenal, the Americans would only share control of those in Europe. ${ }^{109}$ Home appeared supportive of the plan at first. In February 1963, he advised the Prime Minister to consider submitting part of the British nuclear arsenal to NATO and the following month argued that Britain could gain some advantage by contributing to the mixed-manned force. Throughout the spring the Foreign Secretary continued to try to persuade Macmillan to support the MLF, seeing the idea as a way of enhancing British prestige in the US, even though it was intended to have the reverse effect. ${ }^{110}$

However, Home was at best ambivalent about the MLF, repeatedly attacking it in private conversations with the Americans. At Nassau, he noted that 'we did not have a single ally in Europe that would allow Germany to have its finger on the trigger'. On visiting Washington in October 1963, he reaffirmed to Kennedy that 'the M.L.F. had hardly a friend in the United Kingdom, ${ }^{111}$ and secured a US pledge to proceed slowly with the idea. He said he was worried that the MLF might prevent a non-dissemination agreement and thought it would cause problems with world opinion. Home remained uninterested in the MLF when he himself became Prime Minister only a few months later. Nevertheless, as Foreign Secretary, he was not publicly disloyal. He tried to shift the debate, arguing that 'it seems to us to be of the first importance to do what we can to form a multi-national nuclear force now'. He 
advocated NATO involvement target selection. ${ }^{112}$ He also defended the idea against Soviet attacks, telling Gromyko that whilst Britain had doubts about the idea, he thought by tying Germany's hands, it would actually prevent proliferation. ${ }^{113}$

The partial Test-Ban Treaty was a concrete step towards this aim. By banning atmospheric testing, it helped reduce nuclear fall out and marked the first step towards the later SALT and START talks. Kendrick Oliver describes the Treaty as 'as much a British achievement as an American and Soviet one'. ${ }^{114}$ Macmillan's contribution was greater than Home's. He cared deeply for the issue and the Treaty owed a great deal to his persistence and determination. The Moscow conference would not have occurred without his spring intervention. At the Birch Grove meeting, the input of other ministers, from both sides, was minimal, ${ }^{115}$ whilst the archives in general contain much more direct correspondence from Macmillan, especially with Kennedy, than on other issues. The Daily Mail described the Treaty as 'Mac's hour of triumph', ${ }^{116}$ and was not alone in praising him.

There is further evidence from the early stages of the treaty process of the Prime Minister sidelining Home. The Foreign Secretary minuted to Macmillan that Britain should join the US in opposing a test moratorium, for fear of a wide-ranging breach with them. ${ }^{117}$ Thus, instead of consulting Home and the Foreign Office on the domestic implications of allowing US testing on Christmas Island, Macmillan asked Sir Norman Brook to give his opinion in a private memorandum. On other occasions however, the Prime Minister sought to inform the Foreign Secretary more than other ministers, suggesting that he valued his opinion. In May 1961 for example, Macmillan minuted that 'I think I ought to send it to [Home] and not to any of the others'. ${ }^{118}$

As negotiations developed, Home's diplomacy constituted a valuable contribution to the Treaty. He worked patiently throughout the summer of 1962 to persuade the US to put a fresh offer to the USSR, which they finally tabled in August. He pressed the US to be more specific and later dissented from 'putting forward at this stage other detailed proposals which have no scientific justification' ${ }^{119}$ Having successfully opposed the US wish to suspend the Geneva Conference, Home even ensured some changes were made in the draft itself. ${ }^{120}$ Moreover, the Foreign Secretary helped negotiate with the Soviets, pressing Gromyko on the destruction of nuclear weapons and inspections. ${ }^{121}$ Finally, Home contributed to the Moscow conference. He met Rusk in April and May 1963, agreeing at the latter meeting to pursue a ban on atmospheric testing if a total ban proved impossible. They held 
another meeting days before the President's Birch Grove visit in June, ${ }^{122}$ to which Macmillan and Kennedy added little.

Home also bore significant responsibility for ensuring co-operation with the US by restraining his chief. He dissuaded Macmillan from proposing a private meeting with Khrushchev in March 1962: 'The charge that we were negotiating away US security would be certain to follow' ${ }^{123}$ Furthermore, the Foreign Secretary toned down Macmillan's messages to Kennedy and advised him against sending an antitesting message as Berlin heated up. He also successfully urged Macmillan to scale down an ambitious plan for a general conference on the Cold War to one that focused on nuclear testing by Britain, the US and the USSR only. ${ }^{124}$ Home's main contribution, however, was in curbing the Prime Minister's enthusiasm for potentially harmful summitry. The Foreign Secretary, like Kennedy, was suspicious of summits, feeling that failure damaged the morale both of the public and the participants. Macmillan's eagerness for summits made the US think he was trying to push Kennedy into over-hasty commitments.

The debates surrounding nuclear weapons reveal some further interesting facets of the relationship between Home and Macmillan on the one hand, and reaffirm the Foreign Secretary's attitude to the US on the other. The Prime Minister was greatly interested in these issues. As such, he took greater responsibility himself, sometimes sidelining Home. This was most pronounced when the debates impacted on the policies about which he was most passionate, namely the Test-Ban Treaty and the British EEC application. In these areas there is evidence that Macmillan purposely deceived Home, something he cannot be seen to do elsewhere. Yet this is balanced by other evidence that he valued his Foreign Secretary's input. Home still played an important role. Macmillan could not do everything and the Foreign Secretary's work, often with Rusk, made things easier for him. The Test-Ban Treaty process illustrates this well. Moreover, Home again restrained Macmillan from acting in ways that could have been damaging to Anglo-American relations. Above all, the Foreign Secretary was determined to ensure that relations remained as positive as possible, no matter how unreasonable the US action. He was not afraid to go against his Cabinet colleagues, as shown by his position on supplying the heat exchanger to France. 


\section{V}

The years 1961-1963 have often been viewed as a high-point in AngloAmerican relations. Of course, Harold Macmillan, in striking up a rapport with the young US President, deserves credit for this. Yet so too does Lord Home, something that the existing literature fails to fully consider. Home was in regular contact with US policy-makers, especially Rusk and Ambassador David Bruce, performing a dual-role. He invariably supported the US against the USSR and aimed to avoid public disagreement, but privately he spoke frankly, especially over Berlin, the MLF and the Congo. In British policy-making, his role was to push the Government towards policies likely to facilitate closer relations. He was usually more pro-American than Macmillan. On Cuban trade, he argued long and hard that Britain should be more cooperative with the US, whilst his position on nuclear sales to France and Israel was far more conciliatory than any of his colleagues. He was prepared to consider reintroducing conscription for the sake of Berlin despite the political drawbacks and even showed some enthusiasm for the MLF. The Congo, and to a lesser extent British Guiana, were the exceptions. Home opposed the US over the Congo, repeatedly threatening to veto UN Security Council resolutions. This can be explained by his passion on the issue, his concern for Rhodesia and other British interests in the area, and his distrust of the UN. It can also be no coincidence that, like in British Guiana, the Soviet threat was relatively low. Home's pro-Americanism often brought him in to conflict with other departments, but he carried weight in the Cabinet and in Whitehall. He was able to convince the Treasury to provide extra funding for Laos and the Board of Trade to agree to extend the COCOM list regarding Cuba. Yet he did not always get his own way and was overruled by the Cabinet on the issue of Cuban trade and nuclear sales to France, among others. Prime ministerial support could be vital. On one occasion Home was only able to secure Cabinet approval for his view when Macmillan joined him in opposition to the Board of Trade.

Home's other great contribution to the alliance was his restraining influence on the Prime Minster. As Lawrence Freedman says, 'Macmillan had a penchant for statesmanlike visions that on close inspection often turned out to be vacuous, but occasionally he hit the right note'. ${ }^{125}$ Home helped to ensure that the 'vacuous visions' did not damage the special relationship. During the Cuban missile crisis, the Prime Minister wanted to make an attempt to prevent war, but his doing so would 
have seriously weakened the American position. Macmillan's enthusiasm for summitry during the negotiations for the Test-Ban Treaty also carried risks. He was a more nervous and volatile character than Home and, as the historiography suggests, they complimented each other effectively in this respect. The Foreign Secretary provided reassurance, and, although his views on the Congo showed that he himself was not immune to pique when passionate about an issue, Home would also calm the Prime Minister's temper. When American conduct over missile sales enraged Macmillan, it was Home that prevented him from exacerbating the situation.

The relationship between Home and Macmillan was a positive one. In contrast to other relationships between Prime Ministers and their Foreign Secretaries, there was a marked absence of personal animosity between them. The two men came from a similar background. Both went to Eton and Oxford, and the Prime Minister was married to the daughter of the Duke of Devonshire. In Government, they had built a solid relationship whilst Home was at the Commonwealth Relations Office. The Prime Minister referred in his diary to Home as one of 'those I trust', ${ }^{126}$ and actively helped the Foreign Secretary to succeed him. Macmillan did involve himself in foreign policy, but there was no explicit division of responsibility. Contrary to Horne's view, Home controlled policy on the Congo. The Prime Minister took little interest until late in the day. He cared more for areas of high-level Cold War tension, but the Foreign Secretary played a greater role here than the existing historiography suggests. Apart from a rare example over nuclear testing, the Prime Minister did not exclude Home from policy-making. In fact, the reverse was true, with the Foreign Secretary often working in concert with Macmillan. This was the case throughout the Cuban missile crisis and largely over Berlin. Despite some disagreement over Laos, they again combined to help prevent a major US military operation. Where Macmillan was involved, Home's role, as the Skybolt crisis showed, was overtly diminished, yet he remained involved. On the Test-Ban Treaty for example, prime ministerial interventions were vital, but Home and Rusk laid much of the groundwork for the successful Moscow Conference.

This all serves to illustrate some features of the special relationship as Home conducted it. There can be no doubt that the American position was pre-eminent, hence the Foreign Secretary's desire to remain close to the US. The influence of British economic decline repeatedly appears. Both Home and Macmillan were desperate to minimize British expenditure, hence their hostility to UN operations in 
the Congo and military contingency planning, and their eagerness to grant British Guiana independence. It also goes some way towards explaining the British preference for negotiation and the nuclear defence strategy. Politically, the case of the Congo demonstrates that Britain was unable to succeed when the US opposed her. However, Britain did benefit from her high levels of access to the US. This enabled policy-makers to counsel against measures with which they disagreed. Sometimes, as on Laos, they were successful. Other times they were not, but at least they were heard. Arguably Britain's greatest benefit came in the defence arena when Macmillan secured Polaris on very favourable terms. From the American perspective, Britain proved to be a loyal friend. This was most notable during the Cuban missile crisis, where personal contacts were especially important. Macmillan provided reassurance to Kennedy, whilst Ormsby-Gore suggested that the blockade be placed closer to the coast to give the Soviets more time to think. By working with Britain over British Guiana, and exploiting her leverage over her, the US was able to ensure that Jagan did not emerge as leader of the newly independent state. Here, like elsewhere, Britain acted to support the US in spite of disagreeing with her. The special relationship thus brought benefits for both parties between 1961 and 1963. Lord Home's contribution to it was of central importance.

\section{NOTES}

${ }^{1}$ Lord Home, The Way the Wind Blows: An Autobiography (London: Collins, 1976), p.142.

2 J. Dickie, The Uncommon Commoner: A Study of Sir Alec Douglas-Home (London: Pall Mall Press, 1964), p.123.

${ }^{3}$ D. R. Thorpe, Alec Douglas-Home (London: Sinclair-Stevenson, 1997), p.208.

${ }^{4}$ N. Ashton, 'Managing Transition: Macmillan and the Utility of Anglo-American Relations', in R. Aldous, and S. Lee, (ed.), Harold Macmillan: Aspects of a Political Life (Basingstoke: Macmillan, 1999), p.242.

${ }^{5}$ E. Hughes, Sir Alec Douglas-Home (London: Housman's, 1964), p.69.

${ }^{6}$ Thorpe, Douglas-Home, p.210.

7 A. Shlaim, P. Jones and K. Sainsbury, British Foreign Secretaries since 1945 (London: Pall Mall Press, 1964), p.149.

8 Dickie, Uncommon Commoner, pp.127-128; O. Wright, 'Macmillan: a View from the Foreign Office', in Aldous and Lee (ed.), Harold Macmillan, p.13.

${ }^{9}$ H. Macmillan, Pointing the Way, 1959-1961 (London: Macmillan, 1972), p.231.

10 J. Ramsden, The Winds of Change: Macmillan to Heath, 1957-1975 (London: Longman, 1996), p.132.

${ }^{11}$ R. Shepherd, 'Alec Douglas-Home; Anthony Eden: A life and Reputation', Contemporary British History, 11:1 (1997), p.154.

${ }^{12}$ Thorpe, Douglas-Home, pp.230, 255.

${ }^{13}$ A. Horne, Macmillan 1957-1986: Volume II of the Official Biography (London: Macmillan, 1989), p. 245 . 
${ }^{14}$ J. P. S. Gearson, Harold Macmillan and the Berlin Wall Crisis, 1958-62: The Limits of Influence and Force (Basingstoke: Macmillan, 1998), p.203.

${ }^{15}$ Wright, 'Macmillan', p.13.

${ }^{16}$ Horne, Macmillan, p.340; Wright, 'Macmillan', p.13.

${ }^{17}$ Dickie, Uncommon Commoner, p.152.

${ }^{18}$ Kilmuir, Earl, Political Adventure: The Memoirs of the Earl of Kilmuir (London: Weidenfeld and Nicolson, 1964), p.313.

${ }^{19}$ G. H. Bennett, British Foreign Policy during the Curzon Period, 1919-24 (Basingstoke: Macmillan, 1995), pp.5, 11.

${ }^{20}$ F. M. Leventhal, Arthur Henderson (Manchester: Manchester University Press, 1989), p.177.

${ }^{21}$ Ibid., pp.139-140.

${ }^{22}$ D. Carlton, MacDonald versus Henderson: The Foreign Policy of the Second Labour Government (London: Macmillan, 1970), pp.221-222.

${ }^{23}$ Lord Butler, The Art of Memory: Friends in Perspective (London: Hodder and Stoughton, 1982), p. 100 .

${ }^{24}$ Quoted in D. R. Thorpe, Selwyn Lloyd (London: Jonathan Cape, 1989), p.279.

25 H. Nicolson, Curzon: The Last Phase 1919-1925: A Study in Post-war Diplomacy (London: Constable, 1934), pp.58-59.

${ }^{26}$ N. J. Ashton, Kennedy, Macmillan, and the Cold War: The Irony of Interdependence (Basingstoke: Palgrave Macmillan, 2002), p.15.

${ }^{27}$ R. Lamb, The Macmillan Years 1957-1963: The Emerging Truth (London: John Murray, 1995), p.5.

${ }^{28}$ Kilmuir, Political Adventure, p.313.

${ }^{29}$ Horne, Macmillan, p.296; Ashton, 'Transition', pp.246-267.

${ }^{30}$ Dickie, Uncommon Commoner, p.133.

${ }^{31}$ Minute by Macmillan, 8 Oct. 1962, quoted in Lamb, Macmillan, p.394; Armstrong to Home, 2 Nov. 1962, quoted in ibid, p. 395.

${ }^{32}$ Home to Macmillan and Butler, 28 March 1961, PRO: PREM 11/3280; Macmillan to Home, 26 March 1961, PRO: PREM 11/3280; Macmillan to Home, 7 July 1961, PRO: PREM 11/3739; Home to Watkinson, 18 July 1961, PRO: PREM 11/3739.

${ }^{33}$ Home to Macmillan, 7 July 1961, PRO: PREM 11/3739; Macmillan to de Zulueta, 23 July 1961, PRO: PREM 11/3739.

${ }^{34}$ Horne, Macmillan, p.406.

${ }^{35}$ Memorandum of Conversation, 19 Dec. 1962, Foreign Relations of the United States [FRUS], 1961 1963, Vol. XX: Congo Crisis (Washington, D.C.: United States Government Printing Office, 1994), p.761

${ }^{36}$ A. James, Britain and the Congo Crisis, 1960-1963 (Basingstoke: Macmillan, 1996), p.x.

37 Annotation by Macmillan, 22 July 1962, on Home to Macmillan, 20 July 1962, PRO: PREM 11/3629; Macmillan to Kennedy, 25 May 1962, PRO: PREM 11/3666.

${ }^{38}$ Home to Rusk, 10 Aug. 1962, PRO: PREM 11/3629.

${ }^{39}$ James, Congo Crisis, p.174.

${ }^{40}$ Minute by Home, 28 Nov. 1961, PRO: FO 371/155107; Minute by Home, 10 Aug. 1962, PRO: FO 371/161501; Stevenson to Ambassador, 25 Sep. 1962, FRUS, 1961-1963, Vol. XX, pp.582-584; Memorandum of Conversation, 19 Dec. 1962, FRUS, 1961-1963, Vol. XX, p.762; Record of Conversation, 21 Dec. 1962, PRO: PREM 11/4084.

${ }^{41}$ Memorandum by Home, 1 Dec. 1961, C 203(61), PRO: CAB 129/107A.

${ }^{42}$ Welensky to Home, 21 April 1961, PRO: FO 371/154954; Memorandum of Conversation, 19 Dec. 1962, FRUS, 1961-1963, Vol. XX, pp.761-762.

${ }^{43}$ Stevenson to Ambassador, 25 Sep. 1962, FRUS, 1961-1963, Vol. XX, pp.582-584.

${ }^{44}$ Memorandum of Conversation, 19 Dec. 1962, FRUS, 1961-1963, Vol. XX, p.761.

${ }^{45}$ The Times, 14 Dec. 1961, quoted in D. Nunnerley, President Kennedy and Britain (London: Bodley Head, 1972), p.203.

${ }^{46}$ Department of State to Leopoldville, 28 Dec. 1961, FRUS, 1961-1963, Vol. XX, pp.338-339.

${ }^{47}$ Memorandum of Conversation, 4 April 1961, FRUS, 1961-1963, Vol. XX, p.118.

${ }^{48}$ Home to Rusk, 29 Nov. 1961, FRUS, 1961-1963, Vol. XX, p.289, note 4.

${ }^{49}$ FRUS, 1961-63, Vol. XX, p.339, note 2.

${ }^{50}$ Stevenson to Ambassador, 25 Sep. 1962, FRUS, 1961-1963, Vol. XX, pp.582-584; Memorandum to the US, 10 Jan. 1962, PRO: FO 371/161486.

${ }^{51}$ Macmillan Diary, 27 Nov. 1962, quoted in Horne, Macmillan, pp.405-406. 
${ }^{52}$ Memorandum of Conversation, 4 April, 1961, FRUS, 1961-1963, Vol. XX, pp.116-117.

${ }^{53}$ Lord Home, 10 Nov. 1961, quoted in James, Congo Crisis, pp.140-141.

${ }^{54}$ D. Rusk, As I Saw it, as told to R. Rusk, ed. D. S. Papp (New York: W. W. Norton), p.196.

${ }^{55}$ Interview, in James, Congo Crisis, p.176.

${ }^{56}$ James, Congo Crisis, p.176.

${ }^{57}$ Macmillan Diary, quoted in Ashton, Interdependence, p.15.

${ }^{58}$ Memorandum of a Conversation, 30 June 1963, FRUS, 1961-1963, Vol. VII: American Republics (Washington, D.C.: United States Government Printing Office, 1996), pp.607-609.

59 'Brief for Prime Minister's Talks with President Kennedy: British Guiana: Talking Points', June 1963, PRO: FO 371/167757; Record of Meeting, 28 June 1963, PRO: FO 371/167758.

${ }^{60}$ Memorandum of Conversation, 30 June 1963, FRUS, 1961-1963, Vol. XII, p.609.

${ }^{61}$ Advance Copy of Record of Conversation, 12 March 1962, PRO: PREM 11/3666.

${ }^{62}$ Home to Rusk, 18 Aug. 1961, FRUS, 1961-1963, Vol. XII (Washington, 1996), p.521; Bruce Diary (Virginia Historical Society, Richmond, Virginia, USA), 27 Feb. 1962; Home to Rusk, 26 Feb. 1962, PRO: PREM 11/3666; Home to Rusk, 18 Aug. 1961, FRUS, 1961-1963, Vol. XII, pp.521-522.

${ }^{63}$ Memorandum by the Foreign Office, Oct. 1962, PRO: FO 371/172601.

${ }^{64}$ Macmillan to Kennedy, 15 June 1963, PRO: FO 371/167757; Record of Meeting, 28 June 1963, PRO: FO 371/167758; FO to Washington, 24 May 1963, PRO: FO 371/167757.

${ }^{65}$ Record of Meeting, 28 June 1963, PRO: FO 371/167758.

${ }^{66}$ Rusk, As I Saw it, pp.225-226.

${ }^{67}$ Home to Macmillan, 27 Aug. 1961, PRO: FCO 73/136.

${ }^{68}$ Memorandum of Conversation, 12 Dec. 1961, FRUS, 1961-1963, Vol. XIV: Berlin Crisis, 19611962 (Washington, D.C.: United States Government Printing Office, 1993), p.665.

${ }^{69}$ Record of Conversation, 5 April 1961, FRUS, 1961-1963, Vol. XIV, p.43; Record of Conversation, 5 June 1961, ibid., p.99.

${ }^{70}$ Shlaim, Jones and Sainsbury, Foreign Secretaries, p.153.

${ }^{71}$ Record of Conversation, 5 April 1961, FRUS, 1961-1963, Vol. XIV (Washington, 1993), p.39; Home to Shuckburgh, 10 Aug. 1961, PRO: FO 371/160543; Memorandum of Conversation, 21 Dec., 1961, FRUS, 1961-1963, Vol. XIV, p.697; Thorpe, Douglas-Home, p.229.

${ }^{72}$ Home to Macmillan, 6 Aug. 1961, PRO: PREM 11/3349; Record of Conversation, 5 Aug. 1961, PRO: FO 371/160541.

${ }^{73}$ Record of a Conversation, 29 March 1962, PRO: FCO 73/136.

${ }^{74}$ Record of Meeting, 5 Aug. 1961, PRO: FCO 73/136; Memorandum of Conversation, 6 Aug. 1961, FRUS, 1961-1963, Vol. XIV, p.302.

${ }^{75}$ FO to Washington, 16 Aug. 1962, PRO: PREM 11/3343.

${ }^{76}$ Home to Macmillan, 14 June 1961, PRO: PREM 11/3347; Macmillan, Pointing the Way, p.389; Ashton, Interdependence, p.56; Minute by Killick, 14 July 1961, PRO: FO 371/161206; Macmillan to Elizabeth II, 5 Aug. 1961, quoted in Macmillan, Pointing the Way, pp.391-392.

${ }^{77}$ Home to Macmillan, 27 May 1961, PRO: FCO 73/136; Home to Macmillan, 25 Sep. 1961, PRO: FO $371 / 160553$.

${ }^{78}$ Macmillan to Home, 4 Nov. 1961, PRO: PREM 11/3612; Macmillan to Waverley, 19 Aug. 1961, quoted in Horne, Macmillan, p.311; Macmillan Diary, 25 Aug. 1961, Macmillan, Pointing the Way, p.393.

${ }_{79}$ The Observer, 17 Oct. 1962, quoted in Nunnerley, Kennedy and Britain, p.74.

${ }^{80}$ Record of a Conversation, 24 June 1962, PRO: PREM 11/3689.

${ }^{81}$ L. V. Scott, Macmillan, Kennedy and the Cuban Missile Crisis: Political, Military and Intelligence Aspects (Basingstoke: Macmillan, 1999), p.182; Home to Erroll, 7 June 1962, PRO: PREM 11/3689.

${ }^{82}$ Errol to Home, 8 June 1962, PRO: PREM 11/3689; Annotation by Macmillan, 8 June 1962, on Errol to Home, 8 June 1962, PRO: PREM 11/3689; Home to Erroll, 15 June 1962, PRO: PREM 11/3689; Memorandum by Erroll, in Scott, Cuban Missile Crisis, pp.25-26; CC 42(62)2, 26 June 1962, PRO: CAB 128/36.

${ }^{83}$ Minute by Slater, 20 March 1963, PRO: FO 371/168179; Erroll to Home, 26 March 1963, PRO: FO 371/168179; Minister of State, Board of Trade to Chief Secretary, Treasury, 9 April 1963, PRO: FO $371 / 168180$.

${ }^{84}$ Note by the Treasury, 12 Aug. 1963, PRO: FO 371/168197; Erroll to Maudling, 26 Aug. 1963, PRO: FO 371/168198; Du Cann to Smithers, 30 Aug. 1963, PRO: FO 371/168198; Smithers to Maudling, 26 Aug. 1963, PRO: FO 371/168197; CC 57(63)4, 24 Sep. 1963, PRO: CAB 128/37.

${ }^{85}$ Record of Meeting, 12 February 1964, PRO: PREM 11/4697. 
${ }^{86}$ Statement on the Cuban Bus Deal, February 1964, PRO: FO 371/174260.

${ }^{87}$ H. G. Nicholas, quoted in Scott, Cuban Missile Crisis, p.184.

${ }^{88}$ Lord Home, Letters to a Grandson (London, 1983), p.114. Emphasis added.

${ }^{89}$ Macmillan Diary, 4 Nov. 1962, quoted in H. Macmillan, At the End of the Day, 1961-1963 (London, 1973), p.216.

${ }^{90}$ H. Macmillan, 15 Nov. 1962, quoted in Thorpe, Douglas-Home, p.248.

91 Memorandum by Butler, 18 Nov. 1962, quoted in Ashton, Interdependence, p.88; H. Evans, Downing Street Diary: The Macmillan Years 1957-1963 (London: Hodder and Stoughton, 1981), p.226.

92 Draft Record of Conversation, 24 Oct. 1962, PRO: FO 371/162379; Record of Conversation, 25 Oct. 1962, PRO: PREM 11/3691; Bruce Diary, 26 Oct. 1962; Roberts to Home, 29 and 31 Oct. 1962, quoted in Thorpe, Douglas-Home, p.246.

${ }^{93}$ Record of Conversation, 5 April 1961, FRUS, 1961-1963, Vol. XIV, pp.36-40; Memorandum of Conversation, 21 Dec. 1961, FRUS, 1961-1963, Vol. XIV, pp.696-701.

${ }^{94}$ Home to Macmillan, 13 July 1962, PRO: PREM 11/3712; Annotation by Macmillan, 15 July 1962 , on Home to Macmillan, 13 July 1962, PRO: PREM 11/3712; C. A. Pagedas, Anglo-American Strategic Relations and the French Problem, 1960-1963: A Troubled Partnership (London: Frank Cass, 2000), pp.215-217; Record of Talk, 7 June, 1962, PRO: PREM 11/3712.

${ }_{95}$ Memorandum by Pemberton-Pigott, 4 July 1962, PRO: FO 371/163339; FO to Washington, 20 July 1962, PRO: FO 371/163339; Note by the Admiralty, PRO: FO 371/163339; Thorneycroft to Macmillan, 10 Oct. 1962, PRO: DEFE 7/2166; Memorandum by Foreign Office officials, PRO: FO $371 / 163339$

${ }^{96}$ Samuel to Home, 13 Sep. 1962, PRO: FO 371/163339; Annotation by Home, on Samuel to Home, 13 Sep. 1962, PRO: FO 371/163339.

${ }^{97}$ Carrington to Home, 8 March 1963, PRO: PREM 11/4151. Macmillan to Home, 12 March 1963, PRO: PREM 11/4151; Home to Macmillan, 18 March 1963, PRO: PREM 11/4151; Annotation by Macmillan, 19 March 1963, on Home to Macmillan, 18 March 1963, PRO: PREM 11/4151.

${ }^{98}$ Home to Macmillan, 28 June 1961, PRO: FCO 73/136.

${ }^{99}$ Macmillan to Kennedy, 18 Aug. 1962, PRO: PREM 11/4933; Minute by Barter, 18 Aug. 1962, PRO: PREM 11/4933.

${ }^{100}$ Hood to Home, 18 Aug. 1962, PRO: PREM 11/4933.

101 J. W. Young, Britain and the World in the Twentieth Century (London: Arnold, 1997), p.171.

102 Memorandum of Conversation, 19 Dec. 1962, FRUS, 1961-1963, Vol. XIII: West Europe and Canada (Washington, D.C.: United States Government Printing Office, 1994), p.1109.

${ }^{103}$ Bruce Diary, 29 March 1962.

${ }^{104}$ Memorandum of Conversation, 19 Dec. 1962, FRUS, 1961-1963, Vol. XIII, pp.1102-1105.

105 Bruce Diary, 19 Dec. 1962.

${ }^{106}$ Macmillan to Butler, 20 Dec. 1962, quoted in Lamb, Macmillan, p.314.

107 Thorpe, Douglas-Home, p.251; Pagedas, Strategic Relations, p.252.

${ }^{108}$ Nunnerley, Kennedy and Britain, pp.187-189.

${ }^{109}$ Home to Macmillan, 24 May 1961, PRO: FCO 73/136.

${ }^{110}$ Home to Macmillan, 23 Feb. 1961, PRO: PREM 11/3326; Home to Macmillan, 22 March 1962, PRO: PREM 11/4150; Home to Macmillan, 24 May 1961, PRO: PREM 11/3328; Pagedas, Strategic Relations, pp.200-201.

${ }^{111}$ Memorandum of Conversation, 19 Dec. 1962, FRUS, 1961-1963, Vol. XIII, p.1097; Record of Conversation, 4 Oct. 1963, PRO: FO 371/173295.

112 Statement by Home, 20 March 1963, PRO: FO 371/173373.

${ }^{113}$ Record of Conversation, 28 Sep. 1963', PRO: FO 371/173295; Record of Discussion, 30 Sep. 1963, PRO: PREM 11/5181.

114 K. Oliver, Kennedy, Macmillan and the Nuclear Test Ban Debate, 1961-63 (Basingstoke: Macmillan, 1998), p.206.

${ }^{115}$ Record of Meeting, 30 June 1963, PRO: PREM 11/4558.

11626 July 1963, quoted in N. Fisher, Harold Macmillan: A Biography (London: Weidenfeld and Nicolson, 1982), p.333.

${ }^{117}$ Home to Macmillan, 14 Oct. 1961, PRO: PREM 11/3592; Home to Macmillan, 18 Oct. 1961, PRO: PREM 11/3592.

${ }^{118}$ Macmillan to de Zulueta, 20 May 1961, PRO: PREM 11/3590. 
119 Memorandum of Conversation, 25 June 1962, FRUS, 1961-1963, Vol. VII: Arms Control and Disarmament (Washington, D.C.: United States Government Printing Office, 1995), p.474; Home to Rusk, c. 5 Aug. 1962, FRUS, 1961-1963, Vol. VII, p.537.

${ }^{120}$ FO to Washington, 3 Sep. 1961, PRO: PREM 11/3591; 'Final Text of the Joint Announcement by the Prime Minister and the President', PRO: PREM 11/3591.

${ }^{121}$ Record of Conversation, 13 March 1962, PRO: FCO 73/136; Record of Conversation 1 Oct. 1963', PRO: FO 371/173295; Memorandum of Conversation, 18 June 1962, FRUS, 1961-1963, Vol. VII, p.591.

${ }_{122}$ Record of Meeting, 27 June 1963, PRO: PREM 11/4586.

${ }^{123}$ Macmillan to Home, 1 March 1962, PRO: FO 371/163116.

${ }_{124}$ Macmillan to Home, 29 Dec. 1961, PRO: FO 371/163113; Home to Macmillan, 31 Dec. 1961, PRO: FO 371/163113.

${ }^{125}$ L. Freedman, Kennedy's Wars: Berlin, Cuba, Laos, and Vietnam (New York: Oxford University Press, 2000), p.265.

${ }^{126}$ Horne, Macmillan, p.342. 